THE PROBLEM OF WEAK RAILROADS 



\title{
THE PROBLEM OF WEAK RAILROADS
}

\author{
Their Relation to an Adequate \\ Transportation System
}

\author{
By \\ JA.MES M. HERRING, Ph.D. \\ Instructor in Geography and Industry \\ Wharton School of Finance and Commerce \\ University of Pennsyliania
}

\author{
Philadelphia \\ UNIVERSITY OF PENNSYLVANIA PRESS \\ 1929
}


PRINTED IN THE

UNITED STATES OF AMERICA

COPYRIGHT 1929

UNIVERSITY OF PENNSYLVANIA PRESS 
TO MY WIFE

JOSEPHINE WEAVER HERRING 
